COLLOQUIA THEOLOGICA OTTONIANA 2/2016, s. 81-92

DOI: $10.18276 /$ cto. $2016.2-05$

\title{
SOLIDARNOŚĆ I KOMUNIKACJA BLISKOŚCI PRZEJAWEM MILOŚCI SENIORA
}

\author{
Robert Nęcek ${ }^{1}$ \\ Uniwersytet Papieski Jana Pawła II w Krakowie
}

\section{Wprowadzenie}

Pragnienie solidarności i komunikacji bliskości między ludźmi jest głęboko zakorzenione w naturze ludzkiej. Toteż papież Franciszek podkreślił, że każdy chrześcijanin ma obowiązek dawać świadectwo miłości do odrzuconych, chorych i starszych ${ }^{2}$. Wyrazem tego świadectwa staje się solidarnośćc która stwarza atmosferę ciepłego przyjęcia i przyjmuje ,życie w czasach, w których dzieci i dziadków obejmuje ta kultura odrzucenia i postrzegani są jako materiał do wyrzucenia”. Dlatego być solidarnym to móc „liczyć na człowieka, to wierzyć, że jest w nim coś stałego, co nie zawodzi"'s. Efektem tak pojętej solidarności jest komunikacja bliskości, która jest „tym bardziej ludzka, im bardziej pomaga ludziom być w pełni ludźmi”. Dlatego - w tak zarysowanej perspektywie zostaną

\footnotetext{
${ }^{1}$ Ks. dr hab. Robert Nęcek - kierownik Katedry Edukacji Medialnej Instytutu Dziennikarstwa i Komunikacji Społecznej Wydziału Nauk Społecznych Uniwersytetu Papieskiego Jana Pawła II w Krakowie; rzecznik prasowy archidiecezji krakowskiej. E-mail: robertus36@wp.pl.

${ }^{2}$ Por. Franciszek, Dzieci i dziadkowie sa nadzieją ludu. Przemówienie do członków włoskiego Ruchu na rzecz Życia, 11.04.2014, „L'Osservatore Romano” 5 (2014), s. 28.

${ }^{3}$ Por. E. Kucharska, Problematyka starzenia się i starości a instytucjonalne formy opieki nad osobami w podeszlym wieku, Kraków 2012, s. 111.

${ }^{4}$ Franciszek, Dzieci i dziadkowie sq nadzieją ludu ..., s. 28.

${ }^{5}$ J. Tischner, Etyka solidarności, Kraków 2000, s. 15.

${ }^{6}$ Franciszek, Prawdziwa wtadza jest stużba, Kraków 2013, s. 400.
} 
przedstawione - miłość, która nie jest nakazem, lecz darem, odpowiedzialność za seniora, komunikacja bliskości, komunikacja cierpienia, komunikacja nadziei i modlitwa jako komunikacja z Bogiem.

\section{Miłość nie nakazem, lecz darem}

Benedykt XVI w encyklice Deus caritas est zauważył, że „nie ma tak sprawiedliwego porządku państwowego, który mógłby sprawić, że posługa miłości byłaby zbędna" . Jest to istotne sformułowanie, gdyż udział uczestniczący w jakimś cierpieniu wykracza poza określoną przynależność instytucjonalną stając się „dobrowolnym i szlachetnym zaangażowaniem osoby w wymianę społeczną". To szlachetne zaangażowanie uświadamia, że należy człowieka traktować jak człowieka. Oznacza to, że „każdy człowiek jest naszym bratem, to tym bardziej słaby, cierpiący i potrzebujący opieki musi znaleźć się w centrum naszej uwagi, aby nikt nie czuł się zapomniany lub odrzucony" ${ }^{\prime 10}$.

Papież, wskazując na Chrystusa, zauważa, że Jego wrażliwość na ludzkie cierpienie zobowiązuje do myślenia o tych, którzy pomagają seniorom w dźwiganiu ich dolegliwości. Chodzi o lekarzy, pielęgniarki, pracowników służby zdrowia, pracowników socjalnych „i tych, którzy sprawują posługę religijną w domach opieki zdrowotnej. Są oni «zasobami miłości», niosącymi pogodę ducha i nadzieję cierpiącym"11. Równocześnie istnieje zagrożenie deprecjacji miłości przez niewłaściwe jej interpretowanie, które przejawia się w ignorowaniu i lekceważeniu zasad etycznych, a niejednokrotnie w realizacji jedynie litery prawa, nie uwzględniając jej ducha ${ }^{12}$.

Warto zauważyć, że miłość nie jest nakazem. Onajest zaproszeniem. Benedykt XVI zauważył, że miłość bardziej niż przykazaniem jest darem. Ostatecznie jest

\footnotetext{
${ }^{7}$ Benedykt XVI, Encyklika „Deus caritas est”, nr 28.

${ }^{8}$ Por. E. Kucharska, Problematyka starzenia się i starości a instytucjonalne formy opieki, s. 111.

${ }^{9}$ Katechizm Kościoła Katolickiego, nr 1913.

${ }^{10}$ Benedykt XVI, Orędzie na XIX Światowy Dzień Chorego, 21.11.2010. „L'Osservatore Romano" 2 (2011), s. 4.

${ }^{11}$ Benedykt XVI, Zasoby miłości - ludzie, którzy daja nadzieję cierpiącym, 1.07.2012, „L'Osservatore Romano" 9-10 (2012), s. 46.

${ }^{12}$ Por. K. Osińska, Ogólne obowiązki lekarza, w: tenże (red.), Refleksje nad etyka lekarska, Warszawa 1990, s. 24.
} 
uczuciem, „które może być lub nie być, lecz które nie może być stworzone przez wolę”13. Tym sposobem „codziennie powinniśmy dziękować Bogu za miłość, której już zaznaliśmy, za miłość, dzięki której jesteśmy tym, czym jesteśmy, za miłość, która pokazała nam, co jest w życiu naprawdę potrzebne" ${ }^{14}$. Dlatego każda działalność lekarska ma wymiar społeczny, gdyż miłość z natury rzeczy otwarta jest na potrzeby innych ${ }^{15}$. Z tej racji osoba starsza nie może być traktowana jak towar w systemie ekonomiczno-finansowym jednostki szpitalniczej, lecz poprzez miłość „ludziom starszym powinniśmy umożliwić wzrastanie w mądrości zgromadzonej przez całe życie" ${ }^{\prime 16}$.

\section{Odpowiedzialność za seniora przejawem solidarności}

Solidarność zobowiązuje do uczestnictwa w odpowiedzialności za seniora. Przejawia się ona $\mathrm{w}$ pragnieniu jego dobra ${ }^{17}$. Tymczasem „często dominuje postawa przeciwna: obojętność, brak zainteresowania, które rodzą się z egoizmu, maskowanego przez pozorne poszanowanie «sfery prywatnej». Także dzisiaj z mocą rozbrzmiewa głos Pana, który wzywa każdego z nas do troszczenia się o bliźniego. Także dzisiaj Bóg nas prosi, abyśmy byli «stróżami» naszych braci, abyśmy tworzyli relacje nacechowane wzajemną troskliwością, zabieganiem o dobro drugiego i o jego pełne dobro"18. Dlatego przykazanie miłości bliźniego wyrabia świadomość odpowiedzialności, dzięki której możliwa jest codzienna afirmacja seniora. Inaczej mówiąc, odpowiedzialność za chorego wyraża się w tym, że „chcemy jego dobra i czynimy to, co dla niego dobre, pragnąc, by otworzył się on na logikę dobra" ${ }^{19}$. Z tej racji odpowiedzialność zakłada miłość już w myśleniu, a myślenie w miłości. Tę obecność miłości w myśleniu „wyraża się postawą wspaniałomyślności. To widać: myślenie dąży do poznania tego, co

${ }^{13}$ Benedykt XVI, Encyklika „Deus caritas est”, nr 16.

${ }^{14}$ Benedykt XVI, Zostaliśmy stworzeni, by być kochani i obdarzać miłościa, s. 34.

${ }^{15}$ Por. K. Osińska, Ogólne obowiązi lekarza, s. 24.

${ }^{16}$ Franciszek, Nie zgadzaj się na zło, Kraków 2013, s. 188.

${ }^{17}$ Por. Benedykt XVI, Praktykowanie miłości bliźniego jest udziałem w nowej ewangelizacji. Przemówienie do członków Koła św. Piotra z okazji przekazania „obola”, 24.02.2012, „L'Osservatore Romano" 4 (2012), s. 37.

${ }^{18}$ Benedykt XVI, Orędzie na Wielki Post 2012, „L'Osservatore Romano” 3 (2012), s. 4-5.

${ }^{19}$ Benedykt XVI, Praktykowanie miłości bliźniego jest udziałem, s. 37. 
jest, a poznać to, co jest, to pozwolić być; to samo przynależy do istoty miłości ona także pozwala być" ${ }^{20}$.

Inaczej mówiąc, wspaniałomyślność polega na wybieraniu dobra, dlatego że jest dobrem, a nie dlatego, że płyną z tego korzyści. Dlaczego wybiera się miłosierdzie? Ano dlatego, że określone dobro narażone jest na utratę ${ }^{21}$. Być odpowiedzialnym to być stałym, wiernym i wywiązującym się ze zobowiązań. Chodzi o to, że wytrwałość i wierność wyzwala w człowieku radość, choć nie zawsze jest ona natychmiastowa ${ }^{22}$. Nie mogą więc dziwić spostrzeżenia znanego krakowskiego kardiologa Andrzeja Szczeklika, że często ludzkie przypadłości są skrytą skargą bycia niekochanym. Zupełnie inaczej żyłby człowiek, gdyby był kochany $^{23}$.

\section{Komunikacja bliskości}

Z solidarnością w sposób nierozłączny związana jest komunikacja bliskości. Pragnienie komunikacji między ludźmi jest głęboko zakorzenione w ludzkiej naturze. W tej perspektywie papież Franciszek zauważył, że komunikacja międzyludzka „oznacza tworzenie więzi między osobami. Komunikacja społeczna rozpoczyna się od konkretnych osób i zwraca się do innych, również konkretnych osób. Budując między nimi relacje, tworzy społeczną tkaninę, na której rozwija się potem życie społeczności”"24. Komunikowanie więc to życzliwe spojrzenie na seniora. Zawsze musi przyjmować postać osobistej relacji. Dlatego komunikacja jest potężną i skuteczną drogą, aby budować z seniorami komunię w Kościele ${ }^{25}$. Podstawową formą nawiązywania relacji z seniorami jest szczera gotowość do dialogu, a dialog „oznacza, że ludzie wyszli z kryjówek, zbliżyli się do siebie, rozpoczęli wymianę zdań. Trzeba znaleźć miejsce do rozmowy”"26. Dlatego nigdy

${ }^{20}$ J. Tischner, Ksiądz na manowcach, Kraków 2007, s. 107.

${ }^{21}$ Por. tamże.

${ }^{22}$ Por. Benedykt XVI, Orędzie na XXVII Światowy Dzień Młodzieży, „L’Osservatore Romano" 5 (2012), s. 11.

${ }^{23}$ Por. A. Szczeklik, Nieśmiertelność. Prometejski sen medycyny, Kraków 2012, s. 43.

${ }^{24}$ Franciszek, Prawdziwa wtadza jest stużba, s. 400.

${ }^{25}$ Por. R. Nęcek, Komunikacja medialna w stużbie godności osoby ludzkiej w świetle nauczania społecznego Kościoła, w: H. Grzmil-Tylutki, Z. Mirek (red.), Godność w perspektywie nauk, Kraków 2012, s. 116.

${ }^{26}$ J. Tischner, Etyka solidarności, s. 17. 
dość „Zwracania uwagi na jakość komunikacji”27. Istotą jakości komunikacji jest rzeczowy język. Jest to język przystający do rzeczy, jest skonkretyzowany i wnoszący światło ${ }^{28}$. Oznacza to konieczność wczucia się w punkt widzenia drugiej strony. Chodzi o uznanie, że druga strona zawsze ma trochę racji. Podejmowanie dialogu w sposób odpowiedzialny to gotowość uczynienia racji seniora częścią mojego spojrzenia na świat, a swojej racji - uczynienia częścią jego wizji rzeczywistości ${ }^{29}$. Zatem dialog oznacza budowanie wzajemności. Z tej racji „W dialogu, który zanim stanie się rozmową, musi najprzód być skierowaniem własnej uwagi w stronę drugiego, tego właśnie, z kim mamy rozmawiać”30.

Komunikacja bliskości przejawia się w empatii. Definiuje się ją jako zdolność do odczuwania emocji i uczuć innych ludzi. Jest to zdolność odnajdywania się w sytuacji rozmówcy i identyfikacji z jego bólem lub radością. Ryszard Kapuściński wprost stwierdzał, że istnieją ludzie zupełnie niezdolni do empatii i budowania więzi z ludźmi. Tymczasem empatia to zdolność do dzielenia strachu z cierpiącym, odczuwanie jego problemów w taki sposób, jakby były własnymi problemami $^{31}$.

\section{Komunikacja cierpienia}

W dokumencie końcowym z Aparecidy - którego współautorem był kardynał Bergoglio - Jesteśmy uczniami i misjonarzami Jezusa Chrystusa, abynasze narody miały w Nim życie, wydanym przez V Ogólną Konferencję Episkopatów Ameryki Łacińskiej i Karaibów, czytamy, że seniorzy, chorzy i cierpiący są „wyzwaniem dla tego, co stanowi istotę pracy Kościoła, jego duszpasterstwa i naszych postaw chrześcijańskich. Wszystko, co dotyczy Jezusa, dotyczy ubogich, a wszystko, co ma związek z ubogimi, przywołuje Jezusa Chrystusa: «wszystko, co uczyniliście jednemu z tych braci moich najmniejszych, mnieście uczynili» (Mt 25,40)"32.

\footnotetext{
${ }^{27}$ Franciszek, Każda władza jest stużba, s. 400.

${ }^{28}$ Por. J. Tischner, Etyka solidarności, s. 17-18.

${ }^{29}$ Por. tamże, s. $18-19$.

${ }^{30}$ Jan Paweł II, Encyklika „, Redemptor hominis”, nr 11.

${ }^{31}$ Por. R. Kapuściński, Dałem głos ubogim. Rozmowy z młodzieżą, Kraków 2008, s. 73; R. Nęcek, Komunikacja medialna w stużbie godności osoby ludzkiej, s. 117-118.
}

${ }^{32}$ Konferencja Episkopatów Ameryki Łacińskiej i Karaibów, Dokument z Aparecidy „,Jesteśmy uczniami i misjonarzami Jezusa Chrystusa, aby nasze narody miaty w Nim życie”, Aparecida 2007 , nr 393. 
Dlatego przez fakt solidarności w cierpieniu i komunikację cierpienia chorzy dają świadectwo o „kulturze życia”, a także „świadectwo o tym, że każda chwila życia jest darem Bożym oraz że człowiek na każdym etapie życia posiada szczególne bogactwa, którymi może się dzielić z wszystkimi" ${ }^{33}$. Warto podkreślić, że solidarność w cierpieniu jest czymś głębiej osadzonym w człowieczeństwie niż choroba. Budzi współczucie i szacunek, ale wyzwala również onieśmielenie. Dlatego istnieje konieczność współuczestnictwa serca, które pomaga przezwyciężyć onieśmielenie i wyzwolić głęboki imperatyw wiary ${ }^{34}$.

Chodzi o to, że cierpienie, wyniszczając człowieka, czyni go jednocześnie niejako ciężarem dla otoczenia. Wówczas senior czuje się skazany na opiekę, życzliwość i ludzką pomoc ${ }^{35}$. Nieprzypadkowo więc Benedykt XVI stwierdził, że „jednostka nie może zaakceptować cierpienia drugiego, jeśli ona sama nie potrafi odnaleźć w cierpieniu sensu, drogi oczyszczenia i dojrzewania, drogi nadziei. Zaakceptować drugiego, który cierpi, oznacza bowiem przyjąć na siebie w jakiś sposób jego cierpienie, tak że staje się ono również moim. Właśnie dlatego jednak, że staje się ono teraz cierpieniem podzielanym, że jest w nim obecny ktoś inny, oznacza to, że światło miłości przenika moje cierpienie" ${ }^{\prime 36}$.

Z drugiej jednak strony - według papieża Ratzingera - „społeczeństwo, które nie jest $\mathrm{w}$ stanie zaakceptować cierpiących ani im pomóc i mocą współczucia współuczestniczyć w cierpieniu, również duchowo, jest społeczeństwem okrutnym i nieludzkim"37. Papieskie słowa są ważne, gdyż cierpienia nie da się wyeliminować. Cierpienie można jedynie ograniczyćc ${ }^{38}$. Jednocześnie nie da się go racjonalnie wytłumaczyćc ${ }^{39}$. Cierpienie można zrozumieć tylko dzięki wierze. Daje ona bowiem możliwość przyjęcia cierpienia i od wewnątrz przetworzenia go $^{40}$. Dlatego w chrześcijaństwie Chrystus „,na ludzkie pytanie o sens cierpienia nie odpowiada

${ }^{33}$ Jan Paweł II, Dar dlugiego życia. Homilia w czasie Wielkiego Jubileuszu ludzi starszych, 17.09.2000, „L'Osservatore Romano” 11-12 (2000), s. 14.

${ }^{34}$ Por. Jan Paweł II, List apostolski ,, Salvifici doloris”, nr 4; E. Kucharska. Problematyka starzenia się $i$ starości a instytucjonalne formy opieki nad osobami w podeszłym wieku, Kraków 2012, s. $113-114$.

${ }^{35}$ Por. Jan Paweł II, List apostolski ,, Salvifici doloris”, nr 27.

${ }^{36}$ Benedykt XVI, Encyklika ,, Spe salvi”, nr 38.

${ }^{37}$ Tamże.

${ }^{38}$ Por. tamże, nr 37.

${ }^{39}$ Por. K. Stachewicz, O cierpieniu i miłosierdziu, „Znak” 4 (2006), s. 20; R. Nęcek, Troska o zdrowie jako zobowiazanie moralne, w: E. Kucharska (red.), Społeczny wymiar zdrowia. Jubileusz 10-lecia Centrum Medycznego Vadimed, Kraków 2012, s. 27-28.

${ }^{40}$ Por. R. Nęcek, Troska o zdrowie jako zobowiązanie moralne, s. 28. 
wprost i nie odpowiada w oderwaniu. Człowiek słyszy Jego zbawczą odpowiedź w miarę, jak sam staje się uczestnikiem cierpień Chrystusa"41. W tej perspektywie papież Franciszek zauważył, że „nawet w cierpieniu nikt nie jest nigdy sam”42. Oznacza to, że wiara wyzwalająca nadzieję i pobudzająca do miłości opiera się na prawdzie o człowiekư ${ }^{43}$. Tymczasem człowieka coraz częściej traktuje się w sposób konsumpcyjny, którego wpierw się wykorzystuje, a następnie porzuca. W ten sposób zrodziła się kultura odrzucenia, stając się kulturą bez przyszłości ${ }^{44}$. W tej perspektywie „,szansa wiary - jak pisał kardynał Ratzinger - jest szansą prawdy; obie się zaciemnia i depcze, lecz nie znikną one nigdy”"45. W tym kontekście „miarę człowieczeństwa określa się w odniesieniu do cierpienia i do cierpiącego. Ma to zastosowanie zarówno w przypadku jednostki, jak i społeczeństwa"46.

\section{Komunikacja nadziei}

Kościół ma świadomość, że komunikacja bliskości promuje uzasadnioną nadzieję w życiu seniora. Jednak nadzieja to nie tylko przekaz treści możliwych do poznania. To nade wszystko zaprzyjaźnienie się z postępem w taki sposób, aby służył on rozwojowi człowieka. Postęp jest postępem wtedy, kiedy wzrasta panowanie rozumu, a ,rozum jest oczywiście pojmowany jako władza dobra i dla dobra. Postęp jest pokonaniem wszelkich zależności - jest postępem ku doskonałej wolności”" Dlatego na pracujących z seniorami ciąży określona odpowiedzialność, budząca w seniorach nadzieję na spokojniejszą przyszłość.

Budzić nadzieję oznacza jednoczyć ludzi, wzbogacać ich życie, przyczyniać się do tworzenia wspólnoty, nie zadowalać się prawdą cząstkową lub tymczasową, przyczyniać się do wzajemnego zrozumienia i stronić od skażenia dwuznacz-

${ }^{41}$ Jan Paweł II, List apostolski ,, Salvifici doloris”, nr 26.

${ }^{42}$ Franciszek, Nawet w cierpieniu nikt nie jest nigdy sam. Audiencja dla uczestników sesji plenarnej Papieskiej Rady ds. Duszpasterstwa Stużby Zdrowia i Chorych, 24.03.2014, „L'Osservatore Romano" 3-4 (2014), s. 36.

${ }^{43}$ Por. R. Nęcek, Troska o zdrowie jako zobowiazanie moralne, s. 28; E. Kucharska. Problematyka starzenia się $i$ starości a instytucjonalne formy opieki nad osobami w podeszlym wieku, Kraków 2012, s. 114.

${ }^{44}$ Por. Franciszek, Dzieci i dziadkowie sq nadzieją ludu..., s. 28.

${ }^{45}$ J. Ratzinger, Stużć prawdzie, Wrocław 1986, s. 66.

${ }^{46}$ Benedykt XVI, Encyklika ,, Spe salvi”, nr 38.

${ }^{47}$ Tamże, nr 18. 
nością ${ }^{48}$. Jeśli z rozwojem czasów nie idzie postęp w formacji etycznej człowieka, to wówczas postęp nie jest postępem, lecz zagrożeniem i beznadzieją ${ }^{49}$. Dlatego konieczna jest ,samokrytyka czasów nowożytnych w dialogu z chrześcijaństwem i jego koncepcją nadziei. W takim dialogu również chrześcijanie, w kontekście ich wiedzy i doświadczeń, winni na nowo uczyć się, czym jest ich nadzieja, co mają do zaoferowania światu, a czego nie mogą oferować. Trzeba, aby z samokrytyką czasów nowożytnych łączyła się samokrytyka nowożytnego chrześcijaństwa, które wciąż od nowa musi uczyć się rozumienia siebie samego, poczynając od swych korzeni" ${ }^{50}$. Warto także podkreślić, że sam przekaz w komunikacji nie tylko informuje. On równocześnie formuje, gdyż słowo staje się substancją przemiany - na gorsze lub na złe. Chodzi więc o nową kulturę, o kulturę nadziei, a „kto ma nadzieję, żyje inaczej; zostało mu dane nowe życie" ${ }^{51}$.

\section{Modlitwa jako komunikacja z Bogiem}

Solidarność z seniorem prowadzi do stworzenia mu atmosfery sprzyjającej modlitwie. Dlatego zaangażowanie na rzecz seniora nie może polegać jedynie na programach pomocy i opieki. Tym bardziej nie chodzi o nadmiar aktywizmu, lecz nade wszystko idzie o uwagę skierowaną na niego i uważanie go za ,jedno z samym sobą" ${ }^{2}$. Religijność seniorów, zwłaszcza seniorów chorych, wyraża się w wyjątkowym dowartościowaniu modlitwy, która przejawia się w komunikacji z Bogiem. Owa modlitewna komunikacja staje się dla nich rzeczywistością głębi i mocy, która przenika całą ich egzystencję ${ }^{53}$. Oznacza to, że „człowiek epoki cyfrowej podobnie jak człowiek epoki jaskiniowej poszukuje w doświadczeniu religijnym dróg przezwyciężenia swej ograniczoności oraz zapewnienia bezpieczeństwa swej niepewnej przygodzie na ziemi. Zresztą życie bez horyzontu transcendentnego nie miałoby poczucia wypełnienia i szczęścia, do którego wszyscy

\footnotetext{
${ }^{48}$ Por. Benedykt XVI, Orędzie na 40. Światowy Dzień Środków Społecznego Przekazu 2006. Środki przekazu: sieć komunikowania, wspólnoty i współdziałania, Watykan 2006, nr 2-3.

${ }^{49}$ Por. Benedykt XVI, Encyklika ,Spe salvi”, nr 22.

${ }^{50}$ Tamże.

${ }^{51}$ Tamże, nr 2.

${ }^{52}$ Franciszek, Adhortacja apostolska „Evangelii gaudium”, 24.11.2013, nr 199.

${ }^{53}$ Por. Benedykt XVI, Radość ptynaca z wiary i wychowanie nowych pokoleń. Do uczestników kongresu diecezji Rzymu, 5.06.2006, „L'Osservatore Romano” 12 (2006), s. 15.
} 
dążymy, jest ono bowiem z natury ukierunkowane ku przyszłości, która jeszcze ma się spełnić" 54 .

Słowa papieskie akcentują modlitewny charakter ludzkich postaw. Przejawia się w nich zaufanie w Bożą Opatrzność i pełnia wewnętrznej wolności. Dodatkowo seniorzy chorzy - poprzez modlitwę w trudnych chwilach - próbują odnowić swoje komunikacyjne relacje z Bogiem i bliźnimi. Dzięki komunikacji z Bogiem człowiek wychodzi poza krąg własnych spraw, odzyskuje zdolność zbliżania się do innych, „Zwłaszcza w chwilach próby” ${ }^{55}$. Owa modlitewna komunikacja przyczynia się nie tylko do udźwignięcia cierpienia, ale niejednokrotnie staje się źródłem naprawy zaniedbanych relacji z najbliższymi i przyjaciółmi. Komunikacja ta zakłada dyskrecję, która „nie wyklucza modlitwy wspólnej”56.

Równocześnie dyskrecja jest wskazana, aby wejść w prywatny i intymny obszar rozmowy z Bogiem. Dlatego dyskrecja jest właściwą „relacją opartą na miłości" ${ }^{57}$. Miłość ta polega na słuchaniu, co się z seniorem dzieje i czego potrzebuje $^{58}$. Wówczas ,łatwiej będziemy znosili cierpienie, tym lepiej będziemy rozumieli innych i będziemy bardziej na nich otwarci" ${ }^{59}$.

\section{Zakończenie}

Reasumując, należy stwierdzić, że chrześcijanin ma obowiązek dawać świadectwo miłości do seniorów, cierpiących i chorych. Wyrazem świadectwa jest solidarność i komunikacja bliskości, obejmujące całościowe spojrzenie na potrzeby seniorów. Dzięki bliskości człowiek odzyskuje każdego dnia swoją godność i innym godność ofiaruje. W takiej perspektywie papież Franciszek stwierdził, że każdego dnia należy „odzyskiwać swoją godność, tę godność, której dziś często się nie ceni, i dlatego na własnej ziemi żyjemy jak na zesłaniu. Pamiętaj o swoim Ojcu, żebyś był pełen wdzięczności" ${ }^{60}$. Pamiętaj o swojej Matce, żebyś był pełen

\footnotetext{
${ }^{54}$ Benedykt XVI, Katecheza o modlitwie, 11.05.2011, KAI 12.05.2015.

${ }^{55}$ Benedykt XVI, Modlitwa umacnia nasza więź z Bogiem Ojcem i otwiera serca na potrzeby ludzi 14.12.2011, „L'Osservatore Romano” 2 (2012), s. 50.

${ }^{56}$ Benedykt XVI, Jezus z Nazaretu. Od chrztu w Jordanie do Przemienienia, t. I, Kraków 2007, s. 115.

${ }^{57}$ Tamże.

${ }^{58}$ Por. Franciszek, Prawdziwa władza jest stużbą, s. 423.

${ }^{59}$ Benedykt XVI, Jezus z Nazaretu..., s. 116.

${ }^{60}$ Franciszek, Prawdziwa wtadza jest stużba, s. 282-283.
} 
wdzięczności. Taka postawa rodzi piękno, gdyż budzi w seniorach nadzieję, a „komunikacja jest tym bardziej ludzka, im bardziej piękna”61.

\section{Bibliografia}

Benedykt XVI, Encyklika ,Spe salvi”, Watykan 2007.

Benedykt XVI, Encyklika „Deus caritas est”, Watykan 2005.

Benedykt XVI, Orędzie na XIX Światowy Dzień Chorego, 21.11.2010, „L'Osservatore Romano" 2 (2011), s. 4.

Benedykt XVI, Orędzie na XXVII Światowy Dzień Młodzieży, „L'Osservatore Romano” 5 (2012), s. 11.

Benedykt XVI, Orędzie na 40. Światowy Dzień Środków Spolecznego Przekazu 2006. Środki przekazu: sieć komunikowania, wspólnoty i wspóldziałania, Watykan 2006.

Benedykt XVI, Zasoby miłości - ludzie, którzy daja nadzieję cierpiacym, 1.07.2012, „L'Osservatore Romano” 9-10 (2012), s. 46.

Benedykt XVI, Praktykowanie miłości bliźniego jest udziałem w nowej ewangelizacji. Przemówienie do czlonków Kola św. Piotra z okazji przekazania „obola”, 24.02.2012, „L'Osservatore Romano” 4 (2012), s. 37.

Benedykt XVI, Radość plynaca z wiary i wychowanie nowych pokoleń. Do uczestników kongresu diecezji Rzymu, 5.06.2006, „L'Osservatore Romano” 12 (2006), s. 15.

Benedykt XVI, Jezus z Nazaretu. Od chrztu w Jordanie do Przemienienia, t. I, Kraków 2007.

Benedykt XVI, List apostolski „Porta fidei”, Watykan 2011.

Benedykt XVI, Adhortacja ,,Sacramentum caritatis”, Watykan 2007.

Benedykt XVI, Orędzie na XX Światowy Dzień Chorego, 2012, „L'Osservatore Romano” 2 (2012), s. 9.

Benedykt XVI, Z Bogiem stawić czolo w chorobie. Modlitwa Maryjna, 5.02.2012, „L'Osservatore Romano" 4 (2012), s. 52.

Franciszek, Dzieci i dziadkowie sq nadzieja ludu. Przemówienie do członków włoskiego Ruchu na rzecz Życia, 11.04.2014, „L'Osservatore Romano” 5 (2014), s. 28.

Franciszek, Nie zgadzaj się na zło, Kraków 2013.

Franciszek, Nawet w cierpieniu nikt nie jest nigdy sam. Audiencja dla uczestników sesji plenarnej Papieskiej Rady ds. Duszpasterstwa Stuzby Zdrowia i Chorych, 24.03.2014, „L'Osservatore Romano” 3-4 (2014), s. 36.

${ }^{61}$ Tamże, s. 403. 
Franciszek, Adhortacja apostolska „Evangelii gaudium”, 24.11.2013.

Franciszek, Prawdziwa władza jest stużbą, Kraków 2013.

Jan Paweł II, List apostolski ,, Salvifici doloris”, 1984.

Jan Paweł II, Encyklika ,,Redemptor hominis”, Watykan 1979.

Jan Paweł II, Dar dtugiego życia. Homilia w czasie Wielkiego Jubileuszu ludzi starszych, 17.09.2000, „L'Osservatore Romano” 11-12 (2000), s. 14.

Kapuściński R., Dałem głos ubogim. Rozmowy z młodzieżą, Kraków 2008.

Katechizm Kościoła Katolickiego, 1994.

Kucharska E., Problematyka starzenia się i starości a instytucjonalne formy opieki nad osobami w podeszłym wieku, Kraków 2012.

Konferencja Episkopatów Ameryki Łacińskiej i Karaibów, Dokument z Aparecidy „Jesteśmy uczniami $i$ misjonarzami Jezusa Chrystusa, aby nasze narody miaty $w$ Nim życie", Aparecida 2007.

Nęcek R., Eucharystia wyrazem solidarności w nauczaniu społecznym Kościoła, w: J. Machniak, L. Mateja (red.), Rozniecić iskrę Bożego Miłosierdzia, Kraków 2006, s. 115.

Nęcek R., Troska o zdrowie jako zobowiazanie moralne, w: E. Kucharska (red.), Spoteczny wymiar zdrowia. Jubileusz 10-lecia Centrum Medycznego Vadimed, Kraków 2012, s. 15-29.

Nęcek R., Komunikacja medialna w stużbie godności osoby ludzkiej w świetle nauczania społecznego Kościoła, W: H. Grzmil-Tylutki, Z. Mirek (red.), Godność w perspektywie nauk, Kraków 2012, s. 115-129.

Osińska E., Ogólne obowiązki lekarza, w: E. Osińska, Refleksje nad etyką lekarska, Warszawa 1990, s. 24.

Pagola J.A., W strone medycyny holistycznej, w: A. Muszala, J. Binnebesel, P. Krakowiak, M. Krobicki, Dolentium Hominum. Duchowni i świeccy wobec ludzkiego cierpienia, Kraków 2011, s. 289.

Ratzinger J., Stużyć prawdzie, Wrocław 1986.

Szczeklik A., Nieśmiertelność. Prometejski sen medycyny, Kraków 2012.

Stachewicz K., O cierpieniu i miłosierdziu, „Znak” 4 (2006), s. 20.

Tischner J., Etyka solidarności, Kraków 2000.

Tischner J., Ksiądz na manowcach, Kraków 2007. 


\title{
SOLIDARNOŚĆ I KOMUNIKACJA BLISKOŚCI PRZEJAWEM MILOŚCI SENIORA
}

\begin{abstract}
Streszczenie
Artykuł porusza zagadnienie solidarności z seniorami i komunikacji z nimi. Te dwie płaszczyzny wyrażają chrześcijańskie świadectwo miłości wobec nich. Dlatego w tak zarysowanej perspektywie autor przedstawia problem miłości, która nie jest nakazem, lecz darem, a także problemy odpowiedzialności za seniora, komunikacji bliskości, komunikacji cierpienia, komunikacji nadziei i modlitwy jako komunikacji z Bogiem. Dlatego solidarność i komunikacja bliskości wyrabiają świadomość odpowiedzialności, dzięki której możliwa jest codzienna afirmacja seniora. Dodatkowo komunikacja bliskości przejawia się w empatii, która jest zdolnością odczuwania emocji i uczuć innych ludzi. W artykule autor zauważa, iż solidarność w cierpieniu jest czymś głębiej osadzonym w człowieczeństwie niż choroba. Budzi współczucie i szacunek, ale wyzwala również onieśmielenie. Dlatego istnieje konieczność współuczestnictwa serca, które pomaga przezwyciężyć onieśmielenie i wyzwolić głęboki imperatyw wiary. Chodzi więc o solidarność i umiejętność komunikacji bliskości.
\end{abstract}

Słowa kluczowe: komunikacja, senior, solidarność, odpowiedzialność

\section{SOLIDARITY AND CLOSENESS COMMUNICATION AS A MANIFESTATION OF SENIOR'S LOVE}

\section{Summary}

The article raises the issue of the solidarity with seniors and communication with them. These two grounds express Christian witness of love for them. Therefore - in such outlined perspective, the author presents the problem of love, which is not an order but the gift, the responsibility for seniors, closeness communication, communication of suffering and hope and prayer as the communication with God. Therefore, the solidarity and closeness communication develop the sense of responsibility, through which the daily affirmation of senior is possible. In addition, the closeness communication is shown in the empathy, which is the ability to sense the emotions and feelings of other people. In the article, the author notes that solidarity in suffering is something deeply rooted in humanity than the disease. It invokes compassion and respect, but also triggers an intimidation. Therefore there is a need for participation of the heart, which helps to overcome the shyness and trigger a deep imperative of faith. So the issue is solidarity and the closeness communication skills.

Keywords: communication, senior, solidarity, responsibility 